NOTABENE

\title{
LEMBAGA PEMASYARAKATAN DAN BUDAYA HUKUM MASYARAKAT
}

\section{Mardjono Reksodiputro}

mreksodiputro@abnrlaw.com

Program Magister Ilmu Hukum Universitas Pancasila

Media massa dan media sosial sibuk membicarakan tentang kekhawatiran masyarakat akan diperlemahnya Komisi Pemberantasan Korupsi (KPK) melalui undang-undang yang dihasilkan oleh DPR, maupun disahkannya Kitab Undang-undang Hukum Pidana (KUHP) baru (Nasional) pada kurun waktu akan selesainya tugas mereka (DPR baru dilantik 2 Oktober 2019). Pada waktu yang bersamaan dibicarakan juga tentang perilaku petugas Polisi yang bertugas menertibkan massa yang berdemonstrasi (24 September 2019) untuk pembatalan UU KPK tersebut.

Kritik tajam diajukan dalam media-media tersebut, menunjukkan keprihatinan mereka atas perilaku anggota DPR maupun kepolisian. Lepas dari setuju atau tidak setuju dengan hal-hal yang diperjuangkan para warga masyarakat melalui demonstrasi ini, saya menghargai kepedulian mereka tentang isyu-isyu yang diperjuangkan. Isyu utama dan mendasar (menurut penafsiran saya) dalam peristiwa ini adalah tentang hak asasi manusia (HAM).

Korupsi pada dasarnya adalah "mencuri harta kekayaan rakyat" (suatu pelanggaran HAM-Rakyat) dan KPK diibaratkan sebagai pahlawan-pembela HAM-Rakyat yang dizalimi oleh DPR dengan memangkas wewenang KPK. Sedangkan KUHP-Baru ditafsirkan juga telah melukai HAM-Rakyat di bidang privasi (khususnya hak-hak perempuan), di bidang kebebasan berpendapat (dianggap membahayakan kebebasan pers) dan mendorong pembentukan "delik-adat" (delik tidak tertulis) yang membahayakan warga negara maupun warga asing "terjebak" melakukan perbuatan yang (sebenarnya) tidak diketahuinya adalah perbuatan terlarang di daerah adat bersangkutan.

Uraian singkat di atas adalah penafsiran saya apa yang dapat terbaca dari perilaku para demonstran yang kemudian menjadi "rusuh", hingga 
menimbulkan kerusakan sejumlah perangkat publik dan swasta yang merugikan negara beberapa milyar rupiah.Tindakan aparat kepolisian (yang dibantu oleh personil TNI) dalam menertibkan demonstrasi, agar tidak menjadi anarki, dianggap terlalu agresif dan keras, sehingga dirasakan sebagai menghalangi HAM-Rakyat untuk menyampaikan pendapat mereka di muka umum.

Kalau benar pendapat saya bahwa masalah pokok dalam demonstrasi yang kemudian menjadi kerusuhan ini, adalah "kesadaran masyarakat akan HAM mereka",maka terdapat isyu yang (menurut saya) juga urgen di demonstrasikan, yaitu mengenai keadaan Lapas di Indonesia. Mengapa keadaan penghuni-penghuni Lapas ini tidak mau diangkat juga oleh para pemrakarsa dan pemimpin demonstrasi itu ? Ini juga menyangkut HAM, meskipun HAM sebagian Rakyat yang ada di dalam Lapas. Memang ada disebut tentang Rancangan UU Pemasyarakatan yang juga dikecam, tetapi kritiknya menyangkut soal hak-hak narapidana pelaku korupsi. Budaya hukum masyarakat rupanya menjadi sangat punitive (punitif-artinya suka menghukum berat) dalam hal pelaku korupsi.

Tentu saya juga tidak suka kepada para pelaku korupsi, tetapi bukankah mereka juga masih warga masyarakat kita? Yang tentunya juga mempunyai keinginan dan memerlukan perlindungan atas HAM mereka ? Sedangkan para narapidana korupsi ini hanya sebagian kecil dari narapidana dalam lapas-lapas di Indonesia. Justru sebagian besar dari warga Lapas-lapas di Indonesia adalah warga masyarakat yang berpendidikan rendah dan lemah di bidang ekonomi. Banyak dari mereka tersangkut masalah narkoba, baik sebagai pengguna ataupun sekaligus penjual secara eceran atau tertangkap menjadi kurir (keledai-pembawa-beban). Bukan bandar, memang ada beberapa bandar yang menjadi napi, tetapi mereka tidak perlu perlindungan HAM lagi.

Kalau mau percaya "kabar-angin", maka banyak dari bandar ini justru tetap dapat menjalankan operasi penjualan narkoba-nya dari dalam Lapas. Jadi dapatlah dikatakan (suka atau tidak suka) sudah ada perlindungan tertentu dari petugas Lapas (dengan kemungkinan back up atasan) untuk mereka. Benar-tidaknya "kabar-angin" ini perlu ada penelitian dari BNN kita.

Pertanyaan yang diajukan kepada saya adalah: "Apa yang perlu diperjuangkan tentang napi non-koruptor, yang terutama adalah anak 
muda "kurang pendidikan", berasal dari keluarga "ekonomi lemah", dan terlibat dalam tindak pidana narkoba ??" Yang perlu diperjuangkan adalah keadaan keadaan lapas-lapas yang mengkhawatirkan di kota-kota besar Indonesia. Pertambahan penghuni lapas, terutama di daerah urban/ perkotaan, menyebabkan banyak Lapas yang penuh-sesak (overcrowded) dihuni napi. Para napi "muda" ini, melalui Lapas yang menjadi semacam "sekolah-peningkatan-kejahatan", akan menjadi generasi yang tidak melihat pelanggaran hukum sebagai sesuatu yang "aib”. Boleh jadi mereka akan menghayati norma yang mendukung "cepat-kaya melalui jalan-pintas cara illegal" dan secara tidak sadar kita telah menciptakan juga koruptorkoruptor masa akan datang.

Apa yang dapat dilakukan oleh Menteri Hukukum dan HAM serta Dirjen Pemasyarakatan kita? Menurut saya melakukan "reformasi-total lembaga pemasyarakatan" "Tujuan reformasi ini adalah menghilangkan overcrowded (kelebihan penghuni)dalam Lapas-lapas dan memungkinkanadanya "penjara terbuka (open prisons). Adapun asas yang segera perlu dikembangkan oleh Dirjen Pemasyarakatan adalah "to protect and uphold the human rights of offenders" dan ini juga akan menguatkan konsep "pemasyarakatan napi dari Menteri Sahardjo tahun 1963", yang sayangnya sudah dilupakan dalam praktek petugas-petuga Lapas. Budaya hukum masyarakat yang punitif pun harus diubah, pendekatan dalam memberantas kejahatan harus didasarkan pada pendekatan rasional yang dilakukan melalui penelitian tentang akar permasalahan berbagai macam kejahatan di Indonesia, seperti korupsi dan narkoba.-

Lihat makalah saya Maret 2019 untuk FH-UKI berjudul "Reformasi Lembaga Pemasyarakatan Implikasi Partisipasi Swasta”, yang menyarankan Lapas Terbuka untuk sebagian napi. 